\title{
PERAN SERTA MASYARAKAT DALAM PEMBANGUNAN
}

\author{
PUBLIC PARTICIPATION IN DEVELOPMENT
}

Andi Rosdianti Razak

Program Studi Ilmu Administrasi Negara Fakultas Ilmu Sosial Dan Ilmu Politik Universitas Muhammadyah Makassar Jl. Sultan Alaudin No. 259 Makassar 90221 Tlp. 0411-866972 ext. 107. Fax. 0411-8655888

\begin{abstract}
Public participation in development have emerged since the enactment of the Act of 1945 and is constitutionally have a clear reference and is a must for anyone involved in the management of natural resources in Indonesia. However, community participation in development in the reform era is still showing a tendency not run perfectly. How is the condition of public participation from the beginning until now not received the proper position in the form of authority and obligation and the right to participate as a community run development, researched. The approach taken is to study literature, using secondary data from the literature, mass media, legislative provisions, also performed a comparative study of the various opinions and understanding of the role of the community. A number of variables that were examined include: statutory provisions, the role of government, forms of interaction and implementation of public participation efforts by the government in the role of the community so that the development can be improved. From the results of the study the implementation of legislation relating to public participation from the old order to the regional autonomy era still can not be run effectively and efficiently.
\end{abstract}

Keywords: public, participation, development.

\begin{abstract}
ABSTRAK
Peran serta masyarakat dalam pembangunan sudah muncul sejak diberlakukannya UU 1945 dan secara konstitusional telah memiliki acuan yang jelas dan merupakan kewajiban bagi siapapun yang terlibat dalam pengelolaan sumberdaya alam di Indonesia. Namun peran serta masyarakat dalam pembangunan di era reformasi ini masih memperlihatkan kecenderungan belum berjalan dengan sempurna. Bagaimana kondisi peran serta masyarakat sejak awal sampai saat ini belum mendapatkan posisi yang tepat dalam bentuk kewenangan dan kewajiban serta hak sebagai masyarakat dalam ikut menjalankan pembangunan, diteliti. Metode pendekatan yang dilakukan adalah dengan studi pustaka, dengan menggunakan data sekunder yang berasal dari literatur, media masa, ketentuan perundangundangan, juga dilakukan studi komperatif dari berbagai pendapat dan pemahaman tentang peran serta masyarakat. Sejumlah variabel yang dikaji antara lain : ketentuan perundang-undangan, peran pemerintah, bentuk interaksi pelaksanaan peran serta masyarakat dan upaya-upaya yang dilakukan pemerintah dalam peran serta masyarakat agar pembangunan dapat ditingkatkan. Dari hasil kajian pelaksanaan peraturan perundang-undangan yang menyangkut peran serta masyarakat sejak orde lama hingga era otonomi daerah masih belum dapat berjalan secara efektif dan efisien.
\end{abstract}

Kata kunci: Masyarakat, Partisipasi, Pembangunan. 


\section{A. PENDAHULUAN}

Peran serta masayarakat dalam pembangunan sudah muncul sejak diberlakukannya UUD 1945 dan secara konstitusional telah memiliki acuan yang jelas dan merupakan kewajiban bagi siapapun yang terlibat dalam pengelolaan sumberdaya alam di Indonesia. Dalam GBHN pembangunan nasional juga telah menyebutkan bahwa untuk meningkatkan kualitas hidup secara bertahap pemanfaatan sumberdaya yang dimiliki negara dilakukan secara bijaksana sebagai landasan pembangunan tahap berikutnya. Oleh sebab itu peningkatan peran serta masyarakat sangat diperlukan dalam pembangunan termasuk dalam proses perencanaan dan pelaksanaan terutama yang menyangkut secara langsung kehidupan dan masa depan mereka. Undang-undang nomor 23 tahun 1997 tentang pengelolaan lingkungan hidup juga menegaskan bahwa setiap orang mempunyai hak dan kewajiban atas lingkungan hidup yang baik dan sehat (Pasal 5 ayat 1). Serta mempunyai hak untuk berperan dalam pengelolaan lingkungan hidup. Pasal berikutnya menengaskan bahwa setiap orang juga berkewajiban memelihara kelestarian fungsi lingkungan hidup serta mencegah dan menanggulangi pencemaran dan perusakan lingkungan hidup (Pasal 6). Peranan informasi dalam pengelolaan lingkungan sangat penting oleh karena itu setiap orang juga berhak atas dan berkewajiban untuk memberikan informasi tentang lingkungan hidup yang benar dan akurat.

Ada tiga hal utama yang harus dilihat sebagai pesan konstitusional dalam kaitannya dengan pengelolaan sumberdaya alam Indonesia, (1) bahwa pengelolaan sumberdaya alam Indonesia haruslah dilihat sebagai upaya untuk memenuhi kepentingan, mayoritas rakyat Indonesia; (2) bahwa pemerintah harus berperan aktif dalam pengaturan pengelolaan sumberdaya alam sebagai manifestasi penguasaan negara terhadap sumberdaya alam; (3) bahwa rakyat dijamin haknya tidak saja untuk berperan serta dalam pengelolaan sumberdaya alam tetapi juga dalam melakukan kontrol terhadap pemerin- tah sebagai lembaga yang telah dimudahkan untuk melakukan pengaturan. Pengalaman selama Indonesia berada dibawah cengkraman orde baru telah membuktikan, bahwa pengingkaran terhadap ketiga hal utama dalam konstitusional ini telah memunculkan persoalan besar terhadap lingkungan hidup Indonesia. Perusakan lingkungan hidup dan pengurasan sumberdaya alam nyaris tidak terkontrol dan disisi lainnya peran serta masyarakat mengalami distorsi yang terus menerus melalui rekayasa berbagai peraturan dan surat keputusan yang dikeluarkan oleh pemerintah. Proses perusakan lingkungan hidup dan pengurasan sumberdaya alam berjalan seiring dengan dikesampingkannya peran serta rakyat. Kontrol sosial yang datang dari luar lingkaran elit (politik dan ekonomi) selama lebih dari 30 tahun kekuasaan orde baru cenderung untuk didiskriminalisasikan tentu saja merupakan pengingkaran terhadap realitas sosial Indonesia. Pemerintah harus merespon serta mengakomodir aspirasi dari reformasi dengan cara memberanikan diri untuk mengundang public debate serta substansi peraturan perundangan harus berorientasi pada keterbukaan dan pemberdayaan masyarakat sipil.

Dari uraian tentang kondisi peran serta masyarakat sejak awal (UUD 1945) sampai saat ini (reformasi, otonomi daerah) belum mendapatkan porsi yang tepat dalam bentuk kewenangan dan kewajiban serta hak sebagai masyarakat dalam ikut menentukan jalannya pembangunan sesuai dengan (UUD 1945 dan UU nomor 23 Tahun 1997 dan otonomi daerah UU nomor 32 Tahun 2004). Atas dasar itu penulis bermaksud untuk mengkaji peran serta masyarakat dalam pembangunan di era otonomi daerah yang juga memperlihatkan kecendrungan belum dapat berjalan dengan sempurna. Kondisi seperti ini telah nampak sejak awal pemerintahan orde lama (19451967), orde baru (1967-1998); orde transisi reformasi pembangunan (Mei 1998-Oktober 1999); orde persatuan nasional (Oktober 1999-Januari 2001); orde kabinet gotong royong (Januari 2001-2004); dan orde kabinet Indonesia bersatu (2004-2009). Tidak sedikit proyek-proyek pembangunan di 
daerah masih sering ditutup-tutupi, sehingga setelah proyek tersebut beroperasi memunculkan permasalahan baru yang menimpa masyarakat itu sendiri. Dalam kondisi seperti ini sangat diperlukan pengembangan dan revitalisasi sektor hukum dibidang pengelolaan lingkungan hidup di era otonomi daerah.

\section{B. PERAN PEMERINTAH ORGANISASI PUBLIK (PEMERINTAHAN INDONESIA)}

Ada enam kali perubahan dalam organisasi publik (pemerintahan) dan memperlihatkan perubahan yang berbeda tetapi ada sejumlah benang merah yang nampak antara perubahan-perubahan itu secara periodik organisasi publik dalam arti pemerintahan negara modern Indonesia dapat dibagi menjadi enam tahapan yaitu :

1. Dibawah kepemimpinan Soekarno (1945-1966) masa orde lama;

2. Dibawah kepemimpinan Soeharto (1967-1998) masa orde baru);

3. Dibawah kepemimpinan Habibie (Mei 1998-Oktober 1999) masa orde transisi;

4. Dibawah kepemimpinan Abdurrahman Wahid (Oktober 1999-Januari 2001) masa kabinet persatuan nasional;

5. Dibawah kepemimpinan Megawati Sukarno Putri (Januari 2001-2004) masa kabinet gotong royong RI;

6. Dibawah kepemimpinan Susilo Bambang Yudoyono (2004-2009) masa kabinet Indonesia bersatu.

Di era Sukarno organisasi publik tidak bisa berorientasi secara efektif karena diterbitkan dalam fragmentasi politik, di era Soharto fragmentasi itu dihilangkan dengan meninggalkan kekuasan politik (monolitik) model ini berlanjut di era Habibie kemudian berbalik lagi seperti di era Suharto ketika Wahid menjadi presiden, kemudian berlanjut di era Megawati Sukarno Putri dan di era Susilo Bambang Yudhoyono sampai saat ini. Pada kenyataannya organisasi publik di setiap periode cenderung untuk melayani kepentingan pemegang kekuasaan daripada melayani publik. Penguasa itu sendiri bersifat plural yaitu terdiri dari para partai pemenang pemilu untuk menghindari konflik yang lebih keras maka semua di koalisi. Pada era Soharto dan Habibie organisasi publik lebih menjolok melayani kepentingan penguasa karena sifat kekuasaannya yang monolitik.

Organisasi publik tidak pernah mendapatkan kesempatan untuk membangun dirinya sendiri sebagai sebuah lembaga yang berkepentingan terhadap kebutuhan publik. Di setiap era organisaisi publik mengalami kegagalan, karena cenderung menjadi tidak peka terhadap lingkungan terutama lingkungan sosial dan akhirnya tidak mampu merespon perubahan dan krisis dan kadangkala memaksakan kehendak yang dikaitkan dengan konsep publik yaitu memaksa setiap orang untuk mengikutinya. Kondisi ini telah sejak awal periode orde baru sampai saat ini di era otonomi daerah telah bermunculan rajaraja kecil disetiap kabupaten/kota. Dan hubungan raja-raja kecil didaerah (desentralisasi) masih terikat dengan raja di raja pusat (sentralisasi) sehingga konflik dan ketimpangan selama ini terjadi adalah paradigma pembangunan yang hanya terfokus pada masalah ekonomi, tidak adanya kebijakan pemerintah yang konsisten dan tidak terkoordinasi dengan baik, kebijakankebijakan tersebut juga tidak berpihak kepada rakyat yang banyak sehingga masyarakatpun merasa tidak diikutsertakan. Jika hal ini tetap dipertahankan dalam otonomi daerah maka akan terjadi konflik kepentingan antara pemerintah daerah, antara pemerintah pusat dengan pemerintah daerah terutama antar anggota masyarakat sendiri (Sihotang, P. Ozon Des 2001).

\section{BENTUK INTERAKSI PELAKSANAAN PERAN SERTA MASYARAKAT}

Peran serta masyarakat dalam kegiatan pembangunan telah tercantum secara konstitusional dalam peraturan perundangan. Peran serta masyarakat ini merupakan kemitraan diantara para stakeholder khususnya pemerintah, swasta dan masyarakat dalam proses pembangunan yang dikenal dengan konsep "Public Private Partnership". 
Hal yang paling mendasar yang perlu dilakukan untuk mencapai konsep tersebut adalah perlu dilakukan pengambilan "kekuatan" masyarakat dalam proses pengambilan keputusan dalam pembangunan. Bentuk interaksi pelaksanaan peran serta masyarakat untuk mencapai kemitraan tersebut dapat dijelaskan dalam tiga bentuk model yaitu model pertama menggambarkan situasi saat awal sejak era orde lama-orde baru dan transisi, dimana interaksi antara pemerintah-swasta begitu kuat sementara disisi lain masyarakat belum berdaya.

Situasi ini menyebabkan interaksi pemerintah-swasta justru mendominasi sekaligus menetukan arah pembangunan. Disini masyarakat hanyalah sebagai obyek pembangunan masyarakat belum menjadi subyek pembangunan itu sendiri. Model kedua tahap ini memperlihatkan interaksi yang seimbang antara stakeholder, yaitu interaksi pemerintah-masyarakat-swasta interaksi ini dapat memberikan pengalaman yang berharga bagi semua pihak bagaimana bergaul di lingkungan mejemuk dalam pengambilan keputusan. Semua pihak bisa belajar sehingga saling menghargai terutama adanya perbedaan pendapat dan musyawarah untuk mencapai kesepakatan. Model ini merupakan metode partisifatif yang paling pas untuk diterapkan dalam pola interaksi. Model ini telah nampak diterapkan di era Abdurrahman Wahid, Megawati Sokarno Putri dan Susilo Bambang Yudhoyono. Model ketiga adalah model yang paling ideal dari bentuk kemitraan pemerintah-masyarakatswasta.

Disini stakeholder sadar betul akan hak dan kewajibannya. Dalam model ini masyarakat tidak lagi harus terlibat langsung secara teknis dalam kontrak-kontrak pembangunan antara pemerintah swasta. Walaupun demikian masyarakat tetap mempunyai kekuatan dalam menentukan arah kontrak sendiri melalui mekanisme demokrasi dan transparansi. Dalam model ini masyarakat menjadi subyek pembangunan bukan lagi sebagai obyek pembangunan dan kedaulatan berada ditangan rakyat tetapi model ini belum dapat dilaksanakan di Indonesia karena peran serta masyarakat masih terabaikan. Ketiga model ini $(1,2,3)$ disajikan dalam bentuk gambar.

\section{UPAYA-UPAYA YANG PERLU DILAKUKAN PEMERINTAH AGAR PERAN SERTA MASYARAKAT DALAM PEMBANGUNAN DAPAT LEBIH DITINGKATKAN}

Dari hasil kajian pengamatan peran serta masyarakat dalam pembangunan di era otonomi daerah tidak luput dengan adanya benang merah kebijakan organisasi publik (pemerintah) sejak orde lama sampai saat ini yaitu adanya perubahan-perubahan yang menampakkan perbedaan dan persamaan dalam melibatkan masyarakat untuk berperan serta dalam pembangunan. Seperti yang telah dijelaskan dimuka bahwa metode 2 adalah model yang sangat realistis yang telah dirasakan masyarakat sejak pergantian atau setelah era transisi dibawah pemerintahan Habibie yaitu sejak era pemerintahan Abdurrahman Wahid, Megawati Sukarno Putri dan Susilo Bambang Yudhoyono pada saat ini. Masyarakat yang tadinya menjadi obyek pembangunan harus diubah posisinya paling tidak sejajar posisinya dengan stakeholder yang lain (pemerintah-swasta).

Namun untuk mencapai model ketiga dimana masyarakat bukan lagi sebagai obyek pembangunan tetapi sebagai subyek pembangunan memerlukan waktu yang cukup lama dan tenaga yang tidak sedikit untuk merubah keadaan. Penerapan otonomi daerah juga menjadi penghalang untuk menuju model ketiga desentralisasi setengah hati masih dirasakan oleh masyarakat. Terbukti bahwa aspirasi masyarakat dalam menentukan diterima atau ditolak suatu kegiatan pembangunan masih ada di tangan pusat. Adanya sidang kabinet yang sangat berpotensi untuk menggagalkan aspirasi masyarakat didaerah, walaupun disektor sumberdaya alam seperti sektor kehutanan dan lingkungan hidup telah ada menteri yang menanganinya. Namun dapat berubah dengan mudah dalam sidang kabinet dengan alasan untuk pertumbuhan ekonomi yang sangat memprihatinkan. Kondisi ini akan memperparah kerusakan sumberdaya alam yang kian 
hari kian meningkat karena perbedaan pendapat yang tidak menghasilkan kesepakatan hanyalah memperparah kerusakan lingkungan hidup. Kalau terus menerus terjadi ketidakseimbangan antara stakeholder, maka pembangunan yang dilaksanakan akan tidak dapat berkelanjutan sehingga perlu pemerintah mengadakan upaya-upaya agar keseimbangan kemitraan dapat tercapai. Bobot bisa dibuat secara seimbang dengan mengurangi dan menambahkan bobot dari ketiga stakeholder tersebut.

Untuk memberikan bobot tambahan pada pihak masyarakat bisa dila-kukan dengan pengembangan sumberdaya manusia, penguatan ekonomi atau pening-katan kesadaran akan hak dan kewajibannya. Untuk mengurangi bobot pemerintah dan swasta bisa dilakukan dengan penaatan ulang atau penyempurnaan kebijakan dan aturan yang telah dilaksanakan dari hasil monitoring dan evaluasi pelaksanaan kebijakan.

Dari hasil kajian di atas ada beberapa yang bisa dilakukan agar peran serta masyarakat dalam pembangunan dapat ditingkatkan antara lain :

1. Hak masyarakat terhadap sumberdaya alam harus diperhatikan;

2. Perlu adanya peningkatan ekonomi masyarakat sehingga masyarakat lebih mandiri dan tidak terlalu tergantung pada pihak-pihak lain;

3. Pengembangan peluang untuk mengambil keputusan yang partisipatif. Proses perencanaan pembangunan yang terpadu dan partisipatif sebagai salah satu tahap yang penting, perlu dikembangkan sehingga semua pihak ikut menentukan arah pembangunan didaerahnya;

4. Ego sektoral harus dihilangkan;

5. Perlu ada komitmen yang tinggi dari pengambil keputusan formal di daerah, karena tanpa dukungan mustahil kebijakan bisa diterapkan;

6. Perlu memperkuat aspek "Public relation" stakeholder, khususnya masyarakat melalui LSM, sehingga semua informasi mengenai kebutuhan pengelolaan lingkungan hidup bisa tersampaikan kepada pihak lain dengan baik;
7. Otonomi daerah harus bisa dilaksanakan secara penuh, sehingga pelaksanaan pengelolaan lingkungan hidup di daerah mempunyai kewenangan untuk bisa memutuskan (Renggana, A. 1999);

8. Revitalisasi ketentuan Pasal 10 ayat c UUPLH No.23 Tahun 1997 yang menyatakan: Pemerintah berkewajiban mewujudkan, menumbuhkan, mengembangkan dan meningkatkan kemitraan antara masyarakat, dunia usaha dan pemerintah dalam upaya pelestarian daya dukung dan daya tampung lingkungan hidup.

\section{E. PENUTUP}

Pelaksanaan peraturan dan perundangundangan yang menyangkut peran serta masyarakat dalam pembangunan sejak orde lama hingga era otonomi daerah masih belum dapat berjalan secara efektif dan efisien. Kondisi seperti ini terasa pada pelaksanaan UUD 1945, UUPLH No. 23 Tahun 1997 dan juga masih terasa dalam pelaksanaan UU No. 32 Tahun 2004. Dalam pelaksanaan UUD 1945, dibawah kepemimpinan orde lama (1945-1966) organisasi publik belum mampu berfungsi seperti sekarang. Bahkan dapat dikatakan tidak ada pelayanan publik yang dilakukan dalam konteks ekonomi dalam arti yang signifikan, karena pemerintahan pada saat itu dijalankan dengan mempertahankan kemerdekaan dan keutuhan NKRI. Sedangkan kebijakan pemerintah dibawah kekuasaan orde baru (1967-1998) telah membuktikan pengingkaran terhadap pesan konstitusional yang mengakibatkan munculnya persoalan besar terhadap lingkungan hidup yaitu perusakan dan pengurasan sumberdaya alam yang tidak terkontrol dan disisi lainnya peran serta masyarakat mengalami distorsi yang terus menerus melalui rekayasa berbagai peraturan dan surat keputusan yang dikeluarkan oleh pemerintah. Kemudian dalam pelaksanaan UU No. 23/1997 dibawah kepemimpinan orde transisi (1998-1999), kabinet persatuan Indonesia (1999-2001), kabinet gotong royong (2001-2004), kabinet Indonesia bersatu (2004-2009), hak dan jaminan masyarakat untuk berperan serta dalam kegiatan pemba- 
ngunan belum mendapatkan ruang yang jelas dan kebijakan pemerintah masih berjalan mekanisme sentralisasi. Dalam pelak-sanaan UU No. 32 Tahun 2004 dibawah kepemimpinan kabinet Indonesia Bersatu (2004-2009) tentang pemerintahan daerah, peran serta masyarakat masih terabaikan, masyarakat masih sebagai obyek pembangunan.

Bentuk interaksi pelaksanaan peran serta masyarakat antara pemerintah-swasta masyarakat masih dalam tahap model kedua, dimana masyarakat yang tadinya menjadi obyek pembangunan akan berubah posisinya sejajar dengan stakeholder lainnya (pemerintahswasta). Bentuk interaksi ini memperlihatkan interaksi yang seimbang antara stakeholder dan merupakan metode partisipatif yang paling pas untuk diterapkan dalam pola interaksi.

Bentuk interaksi model ketiga adalah paling ideal masyarakat tidak lagi harus terlibat langsung secara teknis dalam kontrak-kontrak pembangunan antara pemerintah dan swasta, akan tetapi masyarakat tetap mempunyai kekuatan dalam menentukan arah pembangunan melalui demokrasi dan transparasi. Dalam model ini masyarakat menjadi subyek pembangunan bukan lagi sebagai obyek pembangunan. Model ini belum dapat dilaksanakan di Indonesia karena peran serta masyarakat masih terabaikan. Kalau dilihat dari ketidakseimbangan bobot antara swasta, pemerintah dan masyarakat dalam melaksanakan pembangunan maka pembangunan yang dilaksanakan tidak akan dapat berkesinambungan sehingga pemerintah perlu mengadakan upaya-upaya keseimbangan kemitraan yaitu dengan mengurangi atau menambahkan bobot dari ketiga stakeholder tersebut. Untuk memberikan bobot tambahan pada pihak masyarakat bisa dilakukan dengan pengembangan SDM, penguatan ekonomi atau peningkatan kesadaran akan hak dan kewajiban. Dan untuk mengurangi bobot pemerintah dan swasta bisa dilakukan dengan penataan ulang atau penyempurnaan kebijakan dan ataupun yang telah dilak-sanakan dari hasil monitoring dan evaluasi pelaksanaan kebijakan. Ada delapan butir upaya yang perlu dilakukan pemerintah agar peran serta masyarakat dalam pembangunan dapat lebih ditingkatkan dan guna mendayagunakan dan menghasilgunakan peran serta masyarakat diperlukan enam persyaratan yang perlu dipenuhi dalam pengelolaan lingkungan hidup.

\section{DAFTAR PUSTAKA}

http : www//Pembangunan, Pada tanggal 28 Februari 2011 jam 16.00 Wita

http : www//Perencanaan Pembangunan, Pada tanggal 28 Februari 2011, jam 15.00 Wita

Kunarjo. 2002. Perencanaan dan Pengendalian Program Pembangunan. Jakarta : UIPress

Propenas 2000-2004. 2003. UU No. 25 Th. 2000 Tentang Program Pembangunan Nasional Tahun 2000-2004. Jakarta : Sinar Grafika 